ISSN 2414-1143

Научный альманах стран Причерноморья. 2018. Том 15. № 3

DOI 10.23947/2414-1143-2018-15-3-23-29

UDC $39+008$

\title{
REFLECTION OF PREJUDICES AND STEREOTYPES IN CROSS-CULTURAL COMMUNICATION
}

\author{
(C) Sarat G. Hiyasova, Maida G. Mustafaeva, Farid M. Mustafaev
}

\author{
Dagestan State Pedagogical University \\ Makhachkala, Russia \\ science-almanac@mail.ru
}

\begin{abstract}
Based on various examples, including ones with Dagestan national culture, where a place and role of prejudices and stereotypes in cross-cultural communication are analyzed. Factors in the creation of stereotypes in communication activities involved in business language were identified. There are positive and negative factors that deserve to be emphasized with the presence of stereotypes in the modern culture and in people's minds. An integrated approach to co-education and interaction, relation to formation of stereotypes among youth, older generation and representatives of different nationalities. The analysis of research is of scientific and practical interest for training specialists of Mass Media, public relations, in the practice of usage of problematic-developing education technologies. A negative undertone of prejudices can be overcome by education and changes of public morality. The can also disappear as a result of collapse with existing standards of conduct in a society. New aspects of professional educational activities in teaching and communication in the process of sociocultural exchange were highlighted. An overall result of the analysis is that albeit particularly challenging and almost impossibility of elimination of stereotypes from a modern sociocultural life it is necessary to make joint efforts to overcome negative thinking in cross-cultural communication
\end{abstract} cation

Key words: prejudices, stereotypes, stereotyped way of thinking, culture, consciousness, communi-

\section{[С.Г. Хиясова, М.Б. Мустафраев, Ф.М. Мустафаев Отражение предрассудков и стереотипов в межкультурной коммуникации]}

Опираясь на различные примеры, в том числе на примеры дагестанской национальной культуры, анализируются место и роль стереотипов и предрассудков в межкультурной коммуникации. Выявлены особенности фрормирования стереотипов в коммуникативной деятельности, участвующих в деловом общении. Отмечаются положительные и отрицательные стороны, которые следует подчеркнуть в присутствии стереотипов в современной культуре и сознании людей. Обосновано применение интегрированного подхода к совместному обучению и общению, отношению к формированию стереотипов у молодежи, старшего поколения, представителей разных национальностей. Анализ исследования представляет научно-практический интерес для подготовки специалистов средств массовой информации, общественных связей, в практике использования технологий проблемно-развивающего обучения. Негативную окраску предрассудков можно преодолеть путем просвещения и изменения общественной морали. Также они могут исчезнуть в результате их столкновения с существующими в обществе нормами поведения. Отмечены новые аспекты профессиональной воспитательной деятельности в обучении и общении в процессе социально-культурного обмена. Делается общий вывод о том, что при всей сложности и нередко невозможности изъятия предрассудков и стереотипов из современной социально-культурной жизни необходимо приложить совместные усилия для преодоления негативного типа мышления в межкультурной коммуникации.

Ключевые слова: предрассудки, стереотипы, стереотипный тип мышления, культура, сознание, коммуникация.

Sarat G. Hiyasova - Candidate of pedagogic sciences, associate professor. Dagestan State Pedagogical University, Makhachkala, Russian Federation.

Хиясова Сарат Гасановна - кандидат педагогических наук, доцент. Дагестанский государственный педагогический университет. г. Махачкала, Россия.

Maida G. Mustafaeva- Ph.D. of Philosophy, professor. Dagestan State Pedagogical University. Makhach- 
kala, Russian Federation.

Мустафраева Маида Ганифаевна - доктор фрилософрских наук, профрессор. Дагестанский государственный педагогический университет. г. Махачкала, Россия.

Farid M. Mustafaev - Ph.D. of Philosophy, associate professor of the Department of Legal Studies. Dagestan State Pedagogical University. Makhachkala, Russian Federation.

Мустафраев Фарид Мустафраевич - доктор фрилософрских наук, доцент. Дагестанский государственный педагогический университет. г. Махачкала, Россия.

In the modern multi-ethnic space, in the context of globalization creation of a single comfortable environment for residency of numerous peoples and nationalities is of paramount importance.

In the everyday life, we are often faced with predetermined perception or cliché about representatives of other cultures and nationalities though we might not realize it. It has been argued, that there are no people free from such "patterns» it would be more appropriate to stalk about varying extent of their influence on minds. These perceptions can become a reason for reluctance towards, and misunderstanding of lifestyle of some people by others. At the same time, there might be a number of other obstacles like age-old prejudices embedded in life and behavior of people.

These predetermined perceptions comes to be called as stereotypes. Ethnical stereotype, in turn, (ancient Greek stereos «firm» + typos «imprint», «image») is a simplified, conceptualized, emotionally coloured and quite sustainable image of an ethnical group easily spread on all its representatives [8]. Prejudice are closely connected with stereotypes. It is very important to know how to differentiate them in cross-cultural communication. Prejudice has recently been interpreted as a well-established habitual way of looking at a deep-rooted order of things.

Stereotypes do not exclude a positive evaluation of the other culture. Prejudice appreciate the distinction between existing cross-group differences mostly negatively and even hostile (racism and xenophobia). In the case of prejudice is appropriate to speak about people's attitudes based on a little personal experience, but «prone to a negative evaluation which can hardly change under the influence of additional information» [12].

There are firm grounds to believe that it is difficult to overcome the prejudice because it has been putting in the minds of men for centuries. Centuries-old ethnic traditions, routine, daily life that are often contrary to modern societies can be laid in the prejudice. At the same time, if some researchers interpret prejudice as « being biased against a group or its some individuals» (D. Mayer) others as « antipathy based on wrong or inflexible attitude» (G. Opport).

Prejudice usually reflect value judgment of a person by the other person. For example, historically in the traditional Dagestan society the notions a «husband-breadwinner» and «wife- family carer» were deeply anchored. From one point of view, it is assessed as a good and right tradition, from the other side it is considered as a social remnant. There was a rule also previously in ancestral traditions of peoples of the Caucasus that a man must not help his wife out around the house or go shopping etc. This phenomenon is regarded more by modern culture as a prejudice, which also contradicts to religious norms, for example, Islam. In traditional Dagestan it was also established not to give girls in marriage to another village and also to another tuhum (family). "A good stone better not to throw away from the village» was said here in such occasions. Many families still hang on to this prejudice, which now can be considered as a Dagestan vestigial tradition.

A negative undertone is also expressed in the fact that they make us biased against a person only because he is a representative of a particular group. It is believed that they can be overcome through education and changes of public morality or they should disap- 
pear naturally as a result of a collapse with existing standards of conduct in a society. Unfortunately, by cultivation and support of particular sector of society prejudice become sustainable. Regrettably, the mass media plays here a key role and contributes significantly to consolidation of existing stereotypes following a certainscheme broadcasting ready simplified patterns. Individual differences of representative of different cultures are often ignored here. For example, the Northern Caucasus, and Dagestan in particular, are associated quite often with instability, various conflicts, "Islamic extremism» and other asocial phenomena. Many researchers support the idea that such image of Caucasus is entirely overrated. Thanks to prevalence of such sources, a person already has a set of bias in the case of contact with foreigners and sometimes it means existence of «artificial attitude» towards the representative of other unknown culture.

German preciseness, pedantry, English politeness and at the same time severity and reservedness, French gallantry and amorousness with carelessness, Italian temper, Finnish slowness, Russian " that's fine as it is " is a kist of deep-rooted stereotypes about nations. Such stereotypes exist in all the peoples of Dagestan.

Similar stereotypes were established by the peoples of Dagestan. So, in the category of stereotypical the following image of peoples of Dagestan is often used. Kumyk is loveable, pretty even sometimes sneaky, Laki is cunning, Avar is straightforward, hot-tempered (Kumyks, Laks, Avars are some indigenous ethnic groups of Dagestan). Certainly, existence of sui generis and even unique specific features of the national character cannot be denied. The problem is that such definitions referring to entire populations often prevents from an objective assessment of a person of «another» culture living nearby. Sometimes it happens that characteristics of the human on the stereotypical level is absurd. For example, in modern Dagestan culture in every-day life such expressions can be heard: "you don't look like Laki girl». In the current case, it means, "you are not as cunning as all Laki girl». If they want to point out that a person is intelligent, level-headed, they say «like you are not a real Avar» meaning that all Avars are in majority "straightforward», "hottempered» etc.

In general, if to take a traditional image of Dagestan man or woman as a basis, then according to stereotyped perceptions Dagestan man is decisive, peaceful, sympathetic, fervent, honest, selfless, brave, dashing, resourceful, unstable, strong-willed, and Dagestan woman is kind, modest, a little bit shy and even wild. Researches note that sense of belonging to a nation makes a mark in an unconscious level.

As we have already mentioned, prejudices and stereotypes are closely related notions. At the same time, stereotypes as all phenomena of world around us are of a twofold nature and have some positive and negative impact. Let us talk about some negative sides of stereotyping of our consciousness.

There is evidence that stereotypes used including mass media can make a significant contribution in the formation of a negative public opinion and aim at one or another social or social group for an effect. For example, not long time ago in the recent past Dagestan was more associated with agriculture, rich nature, elegant handmade products, kind openhearted people, but now this place is considered as even a breaking point of Russia. If previously Dagestan talking about his motherland was proud now he is afraid to say it freely. Obviously, it happens because previously Dagestan was associated with beautiful and brave traditions, natural beauty, poems of Ramsul Gamzatov. Nowadays, a person constructs another reality under bright impressions connecting it with instability, war.

For the sake of complete objectivity, such critics in many ways has a background. We all heard about not rare cases of anti-social behaviour of Caucasians. The problem is that some representatives of the region are free from good conduct and it has a certain influence on other people and causes consolidation of a certain image, which works as a stig- 
ma that is almost impossible to remove later. We should mention some of the implications of stereotype influence with which people who leave their region usually face.

For instance, it is not a rare case when people are refused rented accommodation when would-be hosts learn where a person came from. Some people can or not to get their cherished workplace. Some people face neighbours' resentment and antipathy just because of physical resemblance with Caucasians. Summing up, stereotypes frequently prevent people Russian citizens to define themselves, to live comfortably outside their territory.

Stereotypes on the individual level, unfortunately, are rarely reconsidered. Such «preserved» evaluations are accepted and used in everyday communication even if there is no any concrete experience with representatives of a nationality mentioned [5].

As we see it, in a common sense of understanding the word «stereotype», "stereotypical» there is usually a negative meaning as it is associated with unoriginality. But given that such perception of national characters anyway exist in a person's mind, there is no clear attitude towards them in cross-cultural communication. Perception of behavior of representatives of other cultures from its own perspective is characterized as human psychological propensities. Thus, inclinations of many people to substantiate unknown and complicated phenomena with already existing concepts is a human nature. Hence, stereotypes are not new and existed always. The only thing that could change is its content depending on different conditions.

Explaining behavior of representatives of the other culture «the content of casual attribution is largely determined by stereotypical perception of each side of the other's. That is an image of lifestyle, customs and habits that is a system of ethnocultural features the people concerned. A background of such perception consists of simplified mental representations of different categories of people exaggerating similar qualities and ignoring differences» is pointed out by A. Sadohin [7].

Such studies as had been carried out showed that it is impossible to be completely free of the template thinking. Even frequent contact with other nations can be useless. «If in communicating with a representative of another culture there is a peculiarity that works as a conformation of earlier existing perception then it is perpetuated even more following the moto «I saw this myself» [12].

When thinking about sources of origin of stereotypes, researches point out that human inclination to divide people on "us" and "them" plays here not the least part. At the same time "them" can become "us" under certain conditions. For example, Dagestan peoples living there (Avars, Dargins, Lezgins etc) frequently evaluate themselves as "us" and "them". Under the condition of evidence at another, "their territory" this difference is decreasing. Abroad, all Dagestan people are "us" as a principle of All-Dagestan union work.

Describing major trends of producing stereotypes in minds, in cross-cultural communication, researches outline their function named informational. Stable images largely include objective information about world around though significantly summarize features and qualities of other cultures.

Thanks to that we have some vague ideas about the people we have never met in our lives before. For example, we all heard that French people are gallant, Germans are punctual etc. So, despite their shortcomings stereotypes give an opportunity for a person to construct a general view of the world.

"Schematized as it might be as well as generalized, stereotypes of other nations and cultures prepare us for confrontation with other nation and reduce cultural shock» said S.G. Ter-Minasov [9, c. 40]. «Such factors as stereotypical kind of thinking helps to redraft or «digest» our complicated reality. 
"This is the case when a simplified matrix of the surrounding world can be set up at the cell where based on stereotypes certain social groups are included» [1, c. 222]. A certain principle is set in these template patterns, which means, «people are not ready to react differently on phenomena, but prefer generalizing» [1, c. 218]. This phenomenon is particularly relevant in the context of globalization, constantly changing flow of information. Overwhelmed with information, people protect themselves with stereotypes classifying events and phenomena in a more usable format.

The above provides with another definition of stereotypical system as a permanent picture of the world where people as things taking their known to all place and act as everyone expects. For example, "ours» is usually perceived more loyally and positively than «their».

As a result of stereotyping, there is an estimated comparison between their own and a foreign cultures and thus it tries to protect and even justify values and traditions of their group. This is exactly the "protective mechanism that serves to preserve the positive identity of their own cultural group. This distinction is connected with the notion of in-group favoritism, which implies the formation of a more positive image of one's own culture in comparison with others» [1, p. 222]. Negative stereotypes are often attributed to "others" in order to emphasize positive ideas about themselves. In the process of socialization, a person unconsciously adopts the stereotypes prevailing in society.

Thus, the above-mentioned positive aspects of stereotypes and stereotyped way of thinking largely determine their prevalence and "vitality". Modern researchers of intercultural communication all these "pluses" attribute more to the factor of personal selfidentification. From this point of view, stereotypes help people with guidance in a complicated social world, protection to some extent of the norms and values of their culture, creation of a feeling of social and cultural belonging, and explanation and justification of some negligence towards representatives of other groups.

Considering other properties of stereotypes, in many respects they speak about their simplification, evaluation. Although the same property of stereotypes can lead to incorrect estimates of judgments.

So, for example, in our native culture, generalizing various people, even relatives, under our stereotypical representations, we quite often make mistakes.

If this happens to close people and family, then images of other people who are imprinted in our stereotypical co-knowledge certainly will never fully correspond to reality. It is therefore easy to imagine how primitive and schematic our ideas about people living in completely different geographical, economic and cultural conditions are. Hence, it is not surprising that in the communication process of representatives of widely differing cultures with radically different norms and values, misunderstanding of the partner in dialogue frequently occurs.

Estimation of the stereotypes is expressed in the fact that they are often emotionally coloured by likes and dislikes. So, for example, the same features, depending on whether they belong to their own or to someone else's group, cause different estimates. For example, Dagestan's hospitality and generosity, so appealing to different peoples, if desired, or if there is antipathy towards this culture, can be regarded as excessive wastefulness.

Although reverse stereotypes can also occur, when "not their own" culture acts as the opposite of the shortcomings of one's own culture and society. Consequently, this stereotype offers embellished ideas about other countries, different from everyday life.

Thus, as we see, the role of stereotypes is difficult to identify. On the one hand, as noted above, they allow you to order an unfamiliar world around; it is easier for people to guide themselves in the value-semantic aspect. 
On the other hand, we have shown by various examples that stereotypes can in many respects impede intercultural contacts, since their excessive generalization and a too generalized view of representatives of other cultures, exaggerating features of similarity between them and ignoring differences, individual characteristics, are not always taken into account of people. All this leads to the formation of erroneous ideas about other cultures. The main danger is that beyond the seemingly harmless stereotypical attitudes a significant "conflict potential" can hide.

Hence, when communicating with representatives of other cultures, one should take into account the availability, both in them and in themselves, of template perceptions and, if necessary, adjust them. As the researchers of intercultural communication point out, the very «awareness of the stereotyped nature of one's own thinking, the understanding that stereotypes can distort reality, imparting to the individual personality traits attributed to a whole group of people (for example, nations), helps adequately respond in a situation of inter-cultural communication and gives the opportunity to look at it through the eyes of a partner" $[5$, p. 105, 106]. Especially in modern conditions, thanks to the lack of information barriers, the increase of intercultural contacts between people, it is possible to achieve significant successes in overcoming pre-intellect and stereotypical thinking.

\section{Лumepamypa}

1. Грушевицкая Т.Г., Попков В.Д., Садохин А.П. Основы межкультурной коммуникации. М.: ЮНИТИ-ДАНА, 2002.

2. Камалова О.Н. Исследование эмоций и интуиции в современной фрилософии и науке // Гуманитарные и социально-экономические науки. 2007. № 6. С. 70-74.

3. Камалова О.Н., Склярова Е.К. Историко-медицинские музеи Ростовского государственного медицинского университета // История медицины в собраниях архивов, библиотек и музеев / Материалы III Межрегиональной научнопрактической конференции. 2016. С. 184-191.

4. Мустафраева М.Г., Шахова Р.М. Место и роль правовой культуры и правосознания в становлении гражданского общества в современной России // Гуманитарные и социально-экономические науки. 2015. № 1 (80). С. 104-107.

5. Pom Ю. Межкультурная коммуникация: учеб-метод. пособие. М.: ЮНИТИДАНА, 2006.

6. Руденко А.М. Деловые коммуникации: Учебник. Ростов-на-Дону: Феникс, 2013.

7. Садохин А.П. Теория и практика межкультурной коммуникации. М.: ЮНИТИДАНА, 2004. С. 203.

8. Тен Ю.П. Культурология и межкультурная коммуникация. Ростов-на-Дону: Феникс, 2007. С. 93.

9. Тер-Минасова С.Г. Война и мир языков и культур: вопросы теории и практики: учебное пособие. М.: АСТ, 2007. С. 218.

10.Drobotya N., Chaplygina E., Kamalova O., Sklyarova E. Contribution of researchers of Rostov state medical universityto health development of Black Sea region // Научный альманах стран Причерноморья. 2017. № 1 (9).

11. Quasthoff $U$. Soziales Vorurteil und Kommunikationeine sprachwissenschaftliche Analyse des Stereotyps. Frankfurta. M.: Athenäum, 1973. S. 31.

12. Layes G. Interkulturelles Identitätsmanagment // Handbuch Interkulturelle Kommunikation und Kooperation. Bd. 1 (hrsg. von A. Thomas, E.-U. Knast, S. SchrollMachl). Göttingen: Vanderhoeck\& Ruprecht, 2005. S. 117-125,123.

13. Mustafaeva G., Mustafaev M. Role of ethno-confessional factor in international communication inregions of traditional islam spread // Научный альманах стран Причерноморья. 2017. № 2 (10). 


\section{References}

1. Grushevickaya T. G., Popkov V. D., Sadohin A. P. Osnovy mezhkulturnoj kommunikacii [Basis of cross-cultural communication]. Moscow: YUNITI-DANA, 2002. (in Russian)

2. Kamalova O.N. Issledovanie ehmocij i intuicii v sovremennoj filosofii i nauke [Research on emotions and intuition e modern philosophy and scince], Gumanitarnye i socialno-ehkonomicheskie nauki. 2007. V. 6. pp. 70-74. (in Russian)

3. Kamalova O.N., Sklyarova E.K. Istoriko-medicinskie muzei Rostovskogo gosudarstvennogo medicinskogo universiteta, Istoriya mediciny $v$ sobraniyah arhivov, bibliotek i muzeev [Historical-medical Museum of Russian State Medicine University, History of Medicine and Archive of libraries], Materialy III Mezhre-gionalnoj nauchno-prakticheskoj konferencii. 2016. pp. 184-191. (in Russian)

4. Mustafaeva M.G., Shahova R.M. Mesto i rol pravovoj kultury i pravosoznaniya v stanovlenii grazhdanskogo obshchestva v sovremennoj Rossii [Place and role of legal culture in the establishment of civil society in modern Russia], Gumanitarnye i socialno-ehkonomicheskie nauki. 2015. V. 1 (80). pp. 104-107. (in Russian)

5. Rot YU. Mezhkulturnaya kommunikaciya: ucheb-metod. posobie. Moscow YUNITIDANA, 2006. (in Russian)

6. Rudenko A.M. Delovye kommunikacii: Uchebnik [Business communication. Textbook], Rostov-na-Donu: Feniks, 2013. (in Russian)

7. Sadohin A. P. Teoriya i praktika mezhkulturnoj kommunikacii [Theory and Practice of Cross-Cultural Communication]. Moscow: YUNITI-DANA, 2004. 203 p. (in Russian)

8. Ten YU. P. Kulturologiya i mezhkulturnaya kommunikaciya. [Cultural and CrossCultural communication]. Rostov-na-Donu: Feniks, 2007. 93 p. (in Russian)

9. Ter-Minasova S.G. Vojna i mir yazykov i kultur: voprosy teorii i praktiki: ucheb. Posobie. M.: AST, 2007. S. 218.

10. Drobotya N., Chaplygina E., Kamalova O., Sklyarova E. Contribution of researchers of Rostov state medical university to health development of Black Sea region. Science almanac of Black Sea region countries. 2017. No.1 (9). Available at: http://science-almanac.ru

11. Quasthoff U. Soziales Vorurteil und Kommunikationeine sprachwissenschaftliche Analyse des Stereotyps. Frankfurta. M.: Athenäum, 1973. P. 31.

12. Layes G. Interkulturelles Identitätsmanagment // Handbuch Interkulturelle Kommunikation und Kooperation. Bd. 1 (hrsg. von A. Thomas, E.-U. Knast, S. SchrollMachl). Göttingen: Vanderhoeck\& Ruprecht, 2005. pp. 117-125,123.

13. Mustafaeva G., Mustafaev M. Role of ethno-confessional factor in international communication inregions of traditional islam spread. Science almanac of Black Sea region countries. 2017. No. 2 (10). Available at: http://science-almanac.ru 